\title{
Conservation of Historical and Cultural Identity of Small Towns in Russia: The Role of Brands
}

\author{
Nina Konovalova ${ }^{1, *}$

\begin{abstract}
${ }^{1}$ Scientific Research Institute of the Theory and History of Architecture and Urban Planning (NIITIAG), branch of the Federal State Budget Institution "Central Scientific-Research and Project Institute of the Construction Ministry of Russia", Moscow, Russia

*Corresponding author. Email: phuekirjuko@mail.ru
\end{abstract}

\begin{abstract}
Nowadays, the development of small towns of Russia is implemented in a large part thanks to the touristic industry. In the most ancient Russia towns they try to protect the existing historical and architectural environment, to organize the quality restoration of the monuments of architecture. But often it is not enough to make a certain town attractive for tourists. There are many necessary factors for the successful development of a town. Brand is one of tools of working out an original concept of development and protecting historical and cultural identity of a certain town; i.e. brand is a specific philosophy of a certain territory which provides the manifestation of its individuality. Many small towns of Russia set a task of working out their own brands. We mean not a logo, but a complete town's brand with the identity of a town and the strategy of development of that town.
\end{abstract}

Keywords: small towns in Russia, conservation of historical environment, development of the territory, tourist attraction, brand

\section{INTRODUCTION}

The city or town branding is aimed at the manifestation of a certain uniqueness of that place, at the conservation and protection of its cultural identity. In turn, it contributes to the popularization of a town and, therefore, to attraction of tourists, finances, and investments. Thus, we can say that the town brand is a concept which expresses the uniqueness of a certain town, unites its citizens, and serves as a basement for connection of the town and the outer world.

The city/town branding is rather young discipline for Russia. But the relevance of working out a complex of actions aimed at the creation of positive image of a town, and building of a quality strategy of its development is quite strong in Russia. Discussions on the problems of small towns in Russia, their identity, their tourist and investing attractiveness were started as early as in the beginning of 2000-s. At the same time, the first attempts to work with branding of historical towns were made. But serious specialists in the field of branding, as well as some successfully implemented

"This paper was funded by the Science and Technology Development State Program of the Russian Federation for years 2013-2020, Program of Fundamental Research of State Academies of Science for years 2013 - 2020, within Program of Fundamental Researches of Ministry of Construction, Housing and Utilities of the Russian Federation and Russian Academy of Architecture and Construction Sciences, the Research Project 1.6.3. projects appeared in Russia by 2010-s only. For instance, in the town of Semenov, in the Nizhny Novgorod Region, the flow of tourists grew in 5 times after developing its brand as 'the capital of Golden Khokhloma'. The town of Klin, near Moscow, having received, thanks to the unique museum of P.I. Tchaikovsky, the brand of 'Town of Sounds' not only became more attractive for tourists, but started to work out its image intensely in the chosen direction. In recent years, a recording studio was built in Klin, a DJ school was opened. The complexity of developing a town's brand is also related to the fact that the process of branding, with all its basic rules, has to be reconsidered each time for a specific place [1].

The analysis of studies made in various countries allowed us to systematize the experience of foreign colleagues, which is necessary to justify the specifics of the formation of urban identity in our land. In contemporary foreign studies there is a broad spectre of terms for describing the uniqueness of the environment and its identity. The most commonly used concepts are 'place identity', 'urban identity', 'identity in landscape', 'city identity', 'urban place identity', 'local identity', 'city brand identity', 'regional identity', 'territorial identity', 'community identity', as well as related in meaning: 'sense of place', 'urban perception', 'place branding', 'city image', etc. D. Dredge and J. Jenkins are noted in their works that the most general and fundamental is the term 'identity in landscape' [2]. In the studies of foreign 
experts urban identity is presented as a combination of unique peculiarities of a particular area. This view plays an important role in shaping the image of a certain region [3] [4], in attracting tourists [5], in developing a city logo [6], as well as in composing a plan for the development of a certain city or town [7].

We insert the fundamental factors, the presence of which will become the basis for identifying the peculiarities of one or another small town in Russia, and the formation of its brand:

- the uniqueness of climatic and geographical conditions;

- creating some unique products using traditional (ancient) technology;

- local history and famous historical figures;

- legends associated with the town and some local folklore;

- tourist attractions (museums, monuments and memorial sites);

- architectural ensemble, historical buildings and structures;

- events and activities (festivals, holidays, conferences, etc.).

\section{TOWNS OF THE 'GOLDEN RING' OF RUSSIA: PROBLEMS OF ESTABLISHING THE LEADING CONCEPT}

Beside Moscow and St. Petersburg, the most visited cities and towns in Russia are those of the so called 'Golden Ring'. The name of the Golden Ring was attached to them by Journalist Yuri Bychkov in his series of essays 'The Golden Ring' (1967) about eight ancient Russian towns, which he passed by car along a ring route invented by himself. Since then, the name has become widely used not only in tourism, but also at the state level. The lists of towns of the Golden Ring of Russia vary widely, in fact ${ }^{1}$, but many towns strive to get on the official, most stringent list, supposing by right that it would raise their rating and enhance the recognition of their historical and cultural potential. Attaching new towns to the list, on the information from the Association of Tour Operators of Russia, is planned to be carried out according to the principles of the UNESCO World Heritage List, which have a number of mandatory criteria. There are five of them: historical and cultural, recreational and entertainment, infrastructure, tourist information, and transport and

To the official list of eight ancient Russian towns of the 'Golden Ring' (Vladimir, Suzdal', Rostov the Great, Kostroma, Yaroslavl', Ivanovo, Sergiev Posad, and Pereyaslavl' Zalessky), in 2018, they added Uglich. About 20 towns would like to be included into the list. logistics ${ }^{2}$. So, for example, the historical and cultural criterion includes the coordination of new construction works in the historical centre with the conditions for the protection of cultural heritage. Besides, the town should have a large percentage of restored objects.

The Golden Ring includes towns with wellpreserved monuments of old history and culture, with centres of folk crafts. They give a visual representation of the architecture, life, and folk traditions of the country, and accordingly, reflect the culture and identity of the Russian people. It is no exaggeration to say that the Golden Ring is the central tourist destination that shapes the country's image. In the towns of the Golden Ring, you can literally trace the history of Russia, all the stages of its gradual formation and development. For a long time, the name of the 'Golden Ring' itself served as a brand that raised the status of its towns and, accordingly, attracted tourists. At the end of the twentieth century, when small historical towns were also affected with the economic problems of the whole state, they were the first to feel the decline in the tourist interest to the Golden Ring area. Some problems related to the conservation of historical and cultural heritage, the insufficient development of the tourist industry and the lack of work over the image of those towns were revealed.

The most famous and visited by tourists (both Russian and foreign) of the towns of the Golden Ring is Suzdal'. This is a town with ancient history, wellestablished traditions, and a broad set of expectations from different groups of the population. Suzdal' deserved the glory of 'the town Number One among the small town of Russia'. This is a real open-air museum. There are ancient churches and monasteries, a museum of wooden architecture, a preserved unique natural landscape, and unique panoramic views. Besides, they organize annually a festival of cucumber ${ }^{3}-$ a peculiar and unique show in Russia to honour this popular vegetable. It recalls that gardening and farming have long been the main occupation of the town residents. So, local brands were spontaneously formed, making the town recognizable and attractive. Multiple meanings arouse when trying to determine the identity of Suzdal', however, the established traditions of the city only slowed the process of building a unified philosophy. Nevertheless, the work with the town brand, i.e. defining its image and the leading concept of its development went forward, although with great difficulties. Suzdal' chose a rather difficult, but the most correct way - instead of ordering a 'city concept' in

The information is on the official site of the Association of Tour Operators of Russia: https://www.atorus.ru/news/presscentre/new/40960.html

The festival of cucumber in Suzdal' has been taking place since 2000, in one of Saturdays of July, the time of harvesting the vegetable. Since 2008, the festival has got the international status. 
one of the agencies specializing in branding, the town administration is trying to shape the brand from ideas and opinions of representatives of various audiences on the town. It is the only way to make such concept viable and accepted by the majority of residents of the town and this is one of the main components of success. That is how the concept will become an integral part of the town's life.

Over the recent years, active searches for some concepts which could manifest the uniqueness of other towns of the Golden Ring were initiated. There are no successful examples of the implementation of a particular brand concept. However, from this point of view, it is interesting to compare two ancient small towns of the Yaroslavl Region, Uglich and Myshkin, located not far from each other on the Volga River. Uglich has already entered the official list of the Golden Ring, while Myshkin so far remains only in the unofficial. And, despite the fact that Uglich automatically takes advantage of its status as a town of the legendary route, the tourist attractiveness and, consequently, the attendance by tourists of the town of Myshkin is much higher.

\section{THE TOWN OF UGLICH}

Millions of tourists from all over the world play a huge economic role in the life of the town of Uglich, becoming the basis of its dynamically developing touristic industry. Obviously, there are several factors contributing to the enhancement of the town as a tourist centre: the old history of the town; the status of Uglich as a town of the Golden Ring; unique monuments of Old Russian architecture preserved there; the location of the town on the banks of one of the widest stretches of Volga with its beautiful panoramas; creation of new museums in recent years.

Through its history, Uglich passed terrible times of destruction, flooding, and other adversities. As a result of modern construction works in the town centre, the system of visual relationships in the conservation area was largely disrupted. But, despite all the turmoil, the town keeps its unique flavor. It is the specific character, the spirit of the Old Russian town, that attract tourists for a long journey to enjoy the beauty of Uglich living quarters (posad), merchant mansions and wooden houses with lace platbands.

One of the oldest cities in the Upper Volga Region, Uglich is famous for its monastic ensembles, churches of rare beauty and, of course, the Uglich Kremlin. The town was a real treasury of Old Russian architecture. Uglich did not escape the time of destruction, when many of the most valuable monuments were abandoned for decades and had to be literally saved from death, such as the palace of Tsarevich Dimitry [8]. The Church of St Demetrius on the Blood and many other famous buildings of the Uglich Kremlin retained their historical appearance thanks to the great work of professional restorers.

The oldest in Uglich, Alekseevsky Monastery (founded in 1371), located on the Mountain of Fire (Ognevaya), is one of the most interesting architectural monuments of the town. The most famous building of the monastery is its unique church of the Assumption of Our Lady, peculiar with its three tent-roofs, erected in 1628 in the memory of victims of the Time of Troubles. With its harmonious proportions, the church aroused universal admiration and was nicknamed 'Divnaya' (Wonder). B.M. Kirikov vividly and lyrically described its artistic image: "The significance of the dominant crowning the hill facing the whole town, the sublime poetry of the image testify to the memorial significance of the structure. Marvelous is a memorial churchmonument for the fallen people Uglich, solemn and mournful" [9].

After closing the monastery 1920s, the Divnaya Church was used for household needs, and suffered greatly. It passed through several restorations. In 19201925 , the restoration works were supervised by P.D. Baranovsky. In 1956-1961, the restoration was continued by E.G. Efremov and S.E. Novikov.

These examples, as well as many others, not mentioned here, manifest the attempts to preserve the historical and architectural environment of Uglich, which, of course, increases the attractiveness of the town for tourists. It is impossible, however, to unleash the potential of a historical place only by preserving the totality of its sights and monuments; and even a competently made restoration is only one of the components of successful development of the town

The author conducted a survey of ten largest travel agencies in Moscow and processed data on the activities of those companies in the field of sending tourist groups from Moscow to small towns of Russia. The study showed that Uglich is one of ten small towns of Russia, where tourists stay for more than one day, i.e. they spent at least one night in Uglich hotels. But filling Uglich hotels occurs not only because of the desire of tourists to enjoy the town longer, but mainly because of the desire to see other towns and places located nearby. In percentage terms, the ration is that one: in $97 \%$ of cases, excursion groups visiting Uglich go further to the town of Myshkin. There are other figures: in about $40 \%$ of cases of the excursion program in Myshkin tourists pass Uglich without stopping. Thus, it is obvious that tourists visit Myshkin much more often than Uglich. The questionnaire conducted does not give a general objective picture of tourist activity in relation to these two towns, but it clearly shows that Myshkin is much more popular and 'promoted' as a brand. And this factor, the brand popularity, has been underestimated in Russia for a long time. 
In August 2012, the Italian Chamber of Industry compiled a rating of branded monuments of the world. Monuments, architectural complexes, and groups of attractions were evaluated by experts as brands. Of course, not a word was said about Russia there. It is very difficult for Russian towns to compete with European brands for a number of reasons. And the problem, unfortunately, is not at all in the level of antiquity or uniqueness of one or another architectural monument or ensemble. Drawing a parallel of two cities of the Upper Volga - Uglich and Myshkin — is quite significant for understanding the situation.

\section{THE TOWN OF MYSHKIN}

Updating the legend associated with a particular place is one of the most popular aspects of working with brands of cities around the world. Even in the case of the artificial creation of a legend, if it is accepted by the locals, the image of the city can be very successful. A bright example of such case is the remote mountainous region of Scotland, which has gained popularity and the love of tourists thanks to the legend of the Loch Ness Monster. On the base of this legend, a powerful touristic industry has been formed in Scotland; according to statistics, about 2 million people visit Lake of Loch Ness every year to get a chance to see the Nessie Monster with their own eyes, as well as to listen to old Scottish legends about monsters and dragons in the local museum.

The town of Myshkin, located in a remote part of the Yaroslavl Region, does not have monastic ensembles, ancient religious buildings and fortifications. It is impossible to find a unique architectural monument in the town, which deserves to become a special tourist attraction. However, the flow of tourist groups wishing to visit the small town of Myshkin, only increases from year to year. It seems that the explanation of this situation lies in the field of branding. In the full sense, the revival and prosperity of the city, which can be observed in recent years, is associated with the extremely talented development of its brand. They chose the only promising aspect for its basis - the name of the city - and explained it with a poetic legend. It says that once Prince Mstislavsky ${ }^{4}$, tired of hunting, dozed off on the banks of the Volga River. He was woken up by a mouse, that ran across his face. The prince was angry at first, but when he saw a snake crawling towards him, he realized that the mouse had saved his life. On the spot where he escaped a disaster, the prince ordered to build a chapel in the name of Saints Boris and Gleb and founded the city, calling it Myshkin (literally Mouse's). Currently, a memorial cross is installed on the site of the city's foundation, reminding on the popular legend. Under

\footnotetext{
According to historical chronicles, Princes Mstislavsky got that territory in their hereditary possession about 1526 .
}

Empress Catherine II, a coat of arms with an image of mouse was worked out for the town; nowadays, there is also the Museum of the Mouse, the Mouse Chamber, and, since 1998, they has been organizing the annual festival 'Myshkin Skhodhod'. The strategic importance of the image is enormous.

In this case, a well-chosen brand only attracts tourists, and the image of a calm and nice provincial town lives up to their expectations. The town of Myshkin has kept its historical and cultural identity, the atmosphere of its merchant's past and the quiet rhythm of life. Myshkin is the smallest town of the Yaroslavl Region, characterized with its unique landscape, preserved merchants' houses, a beautiful panorama of the Volga River, and, importantly, a unique aura of the Russian Interior. There are no industrial enterprises, multi-storey buildings, or some extensive public transport network (only a few years ago the first bus route appeared in the town, and so far, the only one there), there is no railway station, no traffic lights. Locals develop traditional crafts and ways of production goods: cooking fish dishes and delicacies, making felt boots and typical Russian doll-amulets.

We emphasize once again that we are not talking about the level of significance or beauty of certain towns. It is exclusively about the development of a town as an attractive place for tourists. But the vast majority of historical towns of our country rely on host tourism as the basis of their economy. Building of attractiveness for the consumer is precisely what the brand serves. Its direct purpose is to increase the degree of recognition, attendance (when it comes to architectural structures), love and affection for a particular memorial place. In European countries, in America, a considerable amount of time and effort is devoted to brand formation and maintenance. In Russia, the situation is almost completely opposite. With all the richness of ancient architectural monuments, in Russia it is considered unnecessary, sometimes even inappropriate, to popularize their values. This situation leads to the fact that many historical and architectural monuments of the country are known only to a narrow circle of specialists. Sometimes, even the locals themselves do not know how great a particular, often dilapidated monument is.

What a well-designed city development program can provide is obvious. The main question is what should it be based on, what factors should be taken into account? The concept of the development program of the town of Myshkin, which so successfully proved its viability, was developed under the leadership of V.L. Glazychev in 1993. Based on the fact that "in relation to its size and formal status, the town of Myshkin had considerable cultural potential, which is the main resource of possible development" [10], V.L. Glazychev was convinced of the impossibility of 
imposing a ready-made strategy, but suggested going "from the inside", taking into account the wishes and needs of the residents of the very town, relying on active enthusiasts. In other words, it may sound like this: something which is important and beloved should be maintained and developed. This specific example shows the reality of this seemingly utopian idea. The result of all the work, according to the accepted hypothesis, is the identification of the cultural potential inherent in each town with its further disclosure. Of course, an important factor is the need to consolidate the development of all participants (not only local residents, but also the administration) in a chosen direction. The methodology of the offered concept of development proved to be very efficient - by the beginning of 2000s, Myshkin had become a paragon of a successful small town, and it remains that one up today.

\section{CONCLUSION}

The methodology that was developed and applied in relation to Myshkin does not lose its relevance and viability at the present time. Built on the basis of intracultural interests, taking into account the constructive proposals of the local population, such a methodology is able to form the basis of the development programs for other towns in Russia. Its value lies, first of all, in revealing a unique potential of one or another small Russian town. And its vitality is given with the fact that the residents of a certain town adopt the concept, which confirms its organic nature. It proves that the basis of an effective brand is the image of a specific town, competent measures to organize, reorganize, and plan the urban environment, taking into account the specifics of a particular town, as well as infrastructure development, measures for the conservation and restoration of architectural monuments. This is the vector of the necessary development of any such town and a way to preserve its historical and cultural identity.

\section{References}

[1] A. Shirvani-Dastgerdi, G. De-Luca. Boosting City Image for Creation of a Certain City Brand // Geographica Pannonica. 2019. № 23 (1). P. 23-31. DOI: https:// doi.org/10.5937/gp2320141

[2] D. Dredge, J. Jenkins. Destination Place Identity and Regional Tourism Policy // Tourism Geographies. 2003. № 5 (4). P. 383407. DOI: https://doi.org/10.1080/ 1461668032000129137.

[3] C. Cassinger, J. Eksell. The Magic of Place Branding: Regional Brand Identity in Transition // Journal of Place Management and Development. 2017. № 10 (3). P. 202-212. DOI: https://doi.org/10.1108/JPMD-03-2017-0028.

[4] A. Shirvani-Dastgerdi, G. De-Luca. Boosting City Image for Creation of a Certain City Brand // Geographica Pannonica. 2019. № 23 (1). P. 23-31. DOI: https:// doi.org/10.5937/gp2320141 .
[5] A. Stoffelen, D. Vanneste The Role of History and Identity Discourses in Crossborder Tourism Destination Development: AVogtland Case Study // Journal of Destination Marketing \& Management. 2018.Vol. 8. P. 204-213. DOI: https://doi.org/10.1016/j.jdmm.2017.04.003

[6] J. Lu, F. Jiong. Research on City Brand Identity Design Based on Perception // Advances in Affective and Pleasurable Design. AHFE 2019. Advances in Intelligent Systems and Computing. Vol. 952. Cham: Springer, 2019. P. 381-390.

[7] P. Nientied Hybrid Urban Identity - The Case of Rotterdam // Current Urban Studies. 2018. № 6 (01). P. 152-173. DOI https://doi.org/ 10.4236/cus.2018.61008.

[8] S.E. Novikov. Reconstruction of the Town of Uglich at the Edge of the Eighteenth - Nineteenth Centuries (Rekonstruktsiya g. Uglicha na rubeze XVIII - XIX vv.) - In: Architecture and Graphics. Short Abstracts of the Reports by the 27th Research Conference of the Leningrad Civil Engineering Institute (Architectura I grafika. Kratkie soderzaniya dokladov k XXVII nauchnoi konferentsii LISI). Leningrad, 1969. [in Rus.]

[9] B.M. Kirikov. Uglich. Leningrad: 1982. P. 68. [in Rus.]

[10] V.L. Glazychev. The City Environment: the technology of Its Development (Gorodskaya sreda: tehnologiya razvitiya) Moscow, 1995. P. 38. [in Rus.] 